\title{
ДИНАМИКА НАКОПЛЕНИЯ КАЛИЯ В ЛИСТЬЯХ ОГУРЦОВ НА ФОНЕ ОБРАБОТОК БИОФУНГИЦИДОМ НА БАЗЕ БИКАРБОНАТА КАЛИЯ
}

\author{
Стратулат T., Тодираш В., Гушан А., Попа А. \\ Институт Генетики, Физиологии и Защиты Растений МОКН, Республика \\ Молдова. e-mail: tgs.05@mail.ru
}

\begin{abstract}
Investigations were conducted under greenhouse conditions to evaluate the effects of potassium bicarbonate (PB) on powdery mildew of cucumber caused by E. cichoracearum. PB of two concentrations was applied as foliar sprays to cucumber and $\mathrm{K}$ content of the leaf samples was determined by AAC. In the greenhouse, PB provided significant control of powdery mildew with fungal isolates, reducing disease levels by up to $67 \%$. Higher disease pressure reduced the efficacy of $\mathrm{PB}$ on powdery mildew but did not affect the content of the $\mathrm{K}$ in leaves. Application of $\mathrm{KHCO}_{3}$ increased the level of $\mathrm{K}$ in the leaves, which was responsible for the suppression of the disease.
\end{abstract}

Key words: potassium, powdery mildew, greenhouse experiments, cucumbers.

\section{Введение}

Растения живут в постоянно меняющейся среде, которая часто неблагоприятна или стрессорна для их роста и развития. Эти неблагоприятные условия окружающей среды включают как биотический стресс, например, патогенная инфекция и вредители, так и абиотический стресс (засуха, холод, дефицит питательных веществ и избыток соли и т.д.). Калий является одним из основных элементов питания и участвует во многих важных физиологических процессах, протекающих в растении: систем;

активизирует функционирование свыше 60-ти ферментов и ферментных

повышает скорость усвоения азота, образование белка и снижает содержание нитратов в сельскохозяйственной продукции;

$\neg$ повышает содержание сахаридов, включая дисахариды, в узле кущения;

$\square$ усиливает синтез целлюлозы и пектиновых веществ, что увеличивает толщину клеточных стенок и повышает прочность тканей, повышая устойчивость к болезням и вредителям;

снижает интенсивность транспирации и повышает водоудерживающую способность листьев, повышая засухоустойчивость.

Первые предположения о необходимости калия растениям высказал Соссюр в 1804 г. на основании анализа золы растений, в которой всегда присутствовал калий. 
Первые экспериментальные данные об абсолютной необходимости калия растениям были получены Сальм-Горстмаром в 1846 г.

В отличие от азота и фосфора калий не входит в состав органических соединений в растениях, а находится в клетках растений в ионной форме. До сих пор неизвестно ни одно органическое соединение, в состав которого входил бы этот элемент. В клетке калий присутствует в виде растворимых солей в клеточном соке (до $80 \%$ и и частично в виде непрочных комплексов с коллоидами цитоплазмы и может легко вымываться водой (дождями и при поливе), особенно из старых листьев.

Калий называют элементом молодости. Действительно, молодые органы растений содержат калия в 3 - 5 раз больше, чем старые, поскольку его гораздо больше именно в тех клетках, где наиболее интенсивно проходят процессы обмена веществ и деления клеток. Содержание калия обычно больше в листьях, стеблях, черенках, по сравнению с его присутствием в продуктивных частях - в зерне, клубнях, корнеплодах. При недостатке калия в питательной среде происходит отток его из более старых органов и тканей в молодые растущие органы, где он подвергается повторному использованию (реутилизации).

При достаточном содержании калия повышается устойчивость растений к различным заболеваниям. Основные механизмы, обеспечивающие положительное действия калия на устойчивость растений к поражению болезнями это:

1.Непосредственное угнетающее действие солей калия на развитие и размножение патогенных микроорганизмов.

2.Увеличение прочности растительных тканей, толщины клеточных стенок и кутикулы - защитного восковидного слоя (у листьев, стеблей, плодов). Положительное влияние на синтез фенольных соединений - основы многих защитных механизмов растений, а также аргинина - аминокислоты, токсичной для возбудителя фитофтороза.

3.«Пищевой» механизм: в растительных клетках не накапливаются низкомолекулярные растворимые органические соединения, служащие благоприятной питательной средой для развития болезнетворных микроорганизмов.

Многочисленными исследованиями последних 20 лет была показана эффективность применения соединений калия в контроле важных болезней многих сельскохозяйственных культур:

- Повышение устойчивости озимой пшеницы к грибным болезням: мучнистой росе, бурой ржавчине, септориозу и корневым гнилям (рисунок ниже)

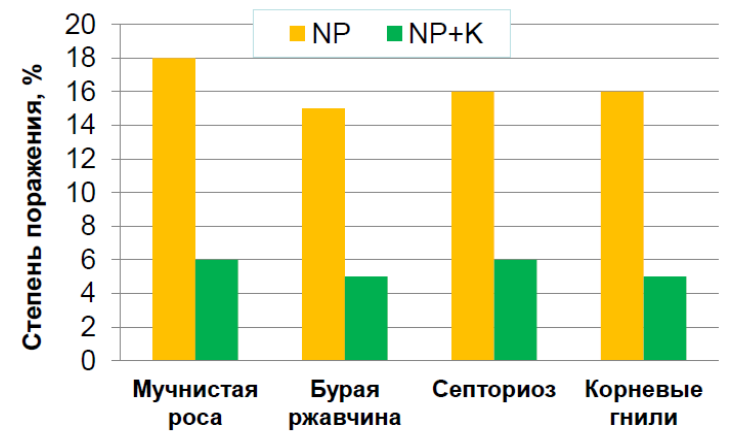


- Повышение устойчивости кукурузы к стеблевым гнилям и роль калия были показаны в исследованиях, проведенных в провинции Цзилинь (Китай), где широко распространены фузариозные стеблевые гнили кукурузы, и одним из доминирующих видов возбудителей является Fusarium graminearum. На фоне применения солей калия степень распространения болезни снижалась с $25 \%$ до 12-14\%, при этом урожайность возрастала с 7,11 до 9,16 т/га (Ji-yun Jin et al., 2007).

Приведенные примеры демонстрируют эффективность калия как фунгицида при его применении для корневой подкормки в виде удобрения. Однако, известно, что степень (процент) и скорость усвоения некоторых элементов питания через листву значительно выше, чем при усвоении из препаратов, внесенных в грунт. Быстрее всего листья усваивают азот, магний, калий, медленнее - серу, еще медленнее фосфор, кальций и микроэлементы. Несмотря на эту разность в скорости проникновения элементов питания в растение, в целом они усваиваются листьями намного быстрее, чем корневой системой из грунта.

Исследованиями ряда авторов было доказано, что листовое применение соединений калия для контроля возбудителей различных болезней является также очень эффективным. Использование пищевой соды (бикарбоната натрия) в качестве фунгицида для контроля мучнистой росы на вьющейся розе было впервые упомянуто в 1933. Соли бикарбоната демонстрируют эффективность против широкого спектра заболеваний на семечковых, косточковых плодовых, ягодных, винограде, хмеле, овощах и декоративных растениях.

Целью данной работы была оценка влияния листовых обработок бикарбонатом калия огурца для контроля мучнистой росы на уровни содержания калия в листьях растения.

1. Вегетационный опыт в теплице

Материалы и методы

1.1 Подготовка растений огурцов.

Саженцы огурцов (Cucumis sativus, F1-гибрид Родничок), были выращены в условиях лаборатории при температуре $26-28^{\circ} \mathrm{C}$ и относительной влажности $75-85 \%$. После получения трех полностью развитых листьев рассаду пересаживали в теплицу, в грунт $\left(24-30^{\circ} \mathrm{C}\right.$ и $65-75 \%$ относительной влажности) на расстоянии 50-60 см в пределах рядов и 150-200 см между рядами и орошали с помощью капельного орошения.

1.2. Приготовление Erysiphe cichoracearum и инокуляция растений огурцов

Инокулят E. cichoracearum был получен из искусственно инфицированных огурцов. Растения содержатся в отдельном инкубаторе в лаборатории. Конидии $E$. cichoracearum собирали с исходных растений по известной методике (Askary et al., 1998; Dik et al., 1998). В течение 2 часов после сбора конидиальную суспензию доводили до $10^{3}$ /мл с помощью гемоцитометра и распыляли на листья рассады огурцов ручным опрыскивателем из расчета 5 мл на лист.

1.3. Подготовка растворов бикарбоната калия (БК).

Готовили водные растворы фунгицида на базе БК (200 г д.в./кг) (разработка ИГФЗР), таким образом, чтобы конечная концентрация раствора для нанесения составляла 0,3 и $0,4 \%$.

1.4. Нанесения препарата на основе БК

Обе изученные концентрации распыляли на листья трехнедельных проростков огурцов за 48 ч до инокуляции возбудителя. Повторную (2-ю) обработку препаратом проводили через 3 дня после начала появления колонии мучнистой росы в опытных 
вариантах, и затем продолжали с 7-дневным интервалом. Всего было выполнено шесть обработок в течение сезона вегетации. Биологическую эффективность оценивали по двум показателям: распространенности (в \%) и интенсивности заболевания (в \%).

2 Подготовка проб листьев огурцов для определения содержания калия

Сроки отбора проб листьев: после 4-х обработок; после 6 обработок; через 3 недели после 6-й обработки; через 1,5 месяца после последней обработки

Пробы листьев отбирали однотипно, по 10 листьев в каждой группе (по одному листу с куста, 7 лист снизу), очищали от пыли и насекомых, затем высушивали на воздухе.

Определение содержания калия.

Для определения содержания калия навеску воздушно-сухой, гомогенизированной пробы листьев массой около 1 грамма, взятой с точностью до 0,0015 г, озоляли при температуре $450-500^{\circ} \mathrm{C}$. Полученную золу растворяли в азотной кислоте (1:1) и количественно переносили в мерную колбу на 50 мл. Для последующего определения калия минерализованный раствор разводили в мерных колбах дистиллированной водой таким образом, чтобы концентрация элемента в растворе находилась в области градуировочного графика. Определение проводилось на атомноабсорбционном спектрометре AAS-1 в режиме эмиссии, в пламени пропан-бутанвоздух.

\section{Результаты и обсуждение}

По данным литературы, результаты испытаний известного препарата Armicarb на основе БК в контроле мучнистой росы на томатах, огурцах, дыне, розмарине, шалфее, кукурузе и салате показали, что эффективность препарата по снижению уровня заболевания была сравнима с эффективностью серы для большинства протестированных культур, и составляла более $90 \%$. При профилактическом применении эффективность препарата была значительно выше.

Результаты выполненных нами исследований показали следующее. Во всех опытных вариантах отмечали отсутствие признаков заболевания как после первой, так и после второй обработок растворами бикарбонатов (смотреть рисунок 1.). В тоже время, распространенность болезни в контроле после первой обработки составляла 18,7 $\%$, а после второй - почти 50 \%. К моменту проведения 3-й, обработки отмечали наличие колоний патогена как в контрольной, так и в опытных группах на всех исследованных дозах. В среднем во всех тестированных группах на фоне применения БК первые признаки болезни проявлялись на листьях на 2-2,5 недели позже, чем в контроле.



Рисунок 1. Динамика интенсивности развития мучнистой росы на огурцах на фоне обработок дозами бикарбоната калия 
Применение $\mathrm{KHCO}_{3}$ оказало значительное влияние на динамику накопления $\mathrm{K}^{+}$ в листьях огурцов. Через 6 недель применения $\mathrm{KHCO}_{3}$ уровень $\mathrm{K}^{+}$в листьях обработанных растений огурцов не превышал контрольного уровня (необработанный контроль). Однако анализ динамики содержания калия после окончания обработок показал, что снижение содержания $\mathrm{K}^{+}$в обработанных листьях было намного ниже этого показателя в контроле, составляя 8,583 г/кг, по сравнению с обработанными вариантами: 11,16 г/кг (0,3 \%) и 10,509 г/кг (0,4 \%). Фактически, содержание калия в листьях обработанных растений было в 1,3 больше чем в контроле (таблица 1) к концу вегетации, что проявилось так же и во внешнем виде растений.

Таблица 1. Динамика изменения уровня содержания калия $\left(\mathrm{K}^{+}\right)$в листьях огурцов, обработанных различными дозами бикарбоната калия на фоне инфицирования мучнистой росой

\begin{tabular}{|c|c|c|c|}
\hline \multirow{2}{*}{ Сроки отбора проб } & \multicolumn{3}{|c|}{ Содержание калия (г/кг) / степень поражения (\%) } \\
\hline & Контроль & $0,3 \% \mathrm{KHCO}_{3}$ & $0,4 \% \mathrm{KHCO}_{3}$ \\
\hline \multirow[t]{2}{*}{ После 2-й обработки } & - & - & - \\
\hline & $20 \%$ & $15 \%$ & $11 \%$ \\
\hline \multirow[t]{2}{*}{ После 4-й обработки } & 15,749 & 11,333 & 12,916 \\
\hline & $75 \%$ & $50 \%$ & $26 \%$ \\
\hline \multirow[t]{2}{*}{ После 6-й обработки } & 13,223 & 12,047 & 10,962 \\
\hline & $80 \%$ & $60 \%$ & $63 \%$ \\
\hline \multirow{2}{*}{$\begin{array}{l}\text { Через } 3 \text { недели } \\
\text { после 6-й обработки }\end{array}$} & 12,416 & 13,315 & 12,570 \\
\hline & $100 \%$ & $100 \%$ & $100 \%$ \\
\hline \multirow{2}{*}{$\begin{array}{l}\text { Через } 1,5 \text { месяца } \\
\text { после 6-й обработки }\end{array}$} & 8,583 & 11,16 & 10,509 \\
\hline & - & - & - \\
\hline
\end{tabular}

\section{Выводы}

Профилактическое применение препарата в обеих концентрациях уменьшает проявление инфекции как по критерию степени распространенности болезни, так и по показателям интенсивности заболевания.

Биологическая эффективность препарата в концентрации 0,4 \% в контроле мучнистой росы огурцов составила около $67 \%$ после 4 обработок.

Уровни содержания калия после 6-ти обработок бикарбонатом $\mathrm{K}^{+}$ свидетельствуют о том, что препарат способствует накоплению калия в обработанных листьях (и в плодах), что повышается устойчивость растений к мучнистой росе и возможно значительно повышает лёжкость плодов (предварительные оценки дали позитивный результат, однако этот вывод требует дополнительных исследований).

\section{Библиография}

1. Прокошев В.В., Дерюгин И.П. Калий и калийные удобрения (Практическое руководство). Издательство: Ледум, 2000 г. 185 стр. ISBN: 5-268-00923-1

2. Jian-Kang Zhu. Abiotic Stress Signaling and Responses in Plants. Cell. Vl. 167, Issue 2, P.313-324, OCTOBER 06, 2016. https://doi.org/10.1016/j.cell.2016.08.029

3. Wenneker M1, Kanne J. (2010). Use of potassium bicarbonate (Armicarb) on the control of powdery mildew (Sphaerotheca mors-uvae) of gooseberry (Ribes uva-crispa)/ Commun Agric Appl Biol Sci. 2010;75(4):563-8. 